\title{
Molecular Characterization and Expression Analysis of Nucleoporin 210 (Nup210) in Chicken
}

\author{
Marc Ndimukaga ${ }^{1}$, Godfrey Bigirwa ${ }^{2}$, Seokhyun Lee ${ }^{3}$, Raham Lee ${ }^{3}$ and Jae-Don $\mathrm{Oh}^{3^{\dagger}}$ \\ ${ }^{I}$ Graduate Student, Department of Animal Biotechnology, College of Agricultural and Life Sciences, Chonbuk National University, \\ Jeonju 54896, Republic of Korea \\ ${ }^{2}$ Graduate Student, Department of Agricultural Convergences, College of Agricultural and Life Sciences, Chonbuk National University, \\ Jeonju 54896, Republic of Korea \\ ${ }^{3}$ Research Professor, Department of Animal Biotechnology, College of Agricultural and Life Sciences, Chonbuk National University, \\ Jeonju 54896, Republic of Korea
}

\begin{abstract}
Nucleoporin 210 (Nup210) is associated with several physiological processes including muscle and neural cell differentiation, autoimmune diseases, and peripheral $\mathrm{T}$ cell homeostasis. Chicken Nup210 (chNup210) gene was originally identified as one of the differentially expressed genes (DEGs) in the kidney tissues of chicken. To elucidate the role of Nup210 in metabolic disease of chicken, we studied the molecular characteristics of chNup210 and analyzed its gene expression under the stimulation of Toll-like receptor 3 (TLR3) ligands. The Nup210 genomic DNA and amino acid sequences of various species including fowls, fishes, and mammals were retrieved from the Ensemble database and subjected to bioinformatics analyses. The expression of Nup210 from several chicken tissues was probed through qRT-PCR, and chicken fibroblast DF-1 cell line was used to determine the change in expression of chNup210 after stimulation with TLR3 ligand, polyinosinicpolycytidylic acid (poly (I:C)). The chNup210 gene was highly expressed in chicken lung and spleen tissues. Although highly conserved among the species, chNup210 was evolutionary clustered in the same clade as that of duck compared to other mammals. Furthermore, this study revealed that chNup210 is expressed in TLR3 signaling pathway and provides fundamental information on Nup210 expression in chicken. Future studies that offer insight into the involvement of chNup210 in the chicken innate immune response against viral infection are recommended.
\end{abstract}

(Key words: chicken, nucleoporin 210, toll-like receptor 3, gene expression, innate immune receptor signaling)

\section{INTRODUCTION}

Nuclear pore complexes (NPCs) are multi-protein channels embedded in the nuclear envelope which mediate molecular transports between the nucleus and cytoplasm. For this nucleocytoplasmic trafficking, NPCs are composed of about 30 different nucleoporins (Nups) regulating the NPC function and small receptors called importin and exportin which coordinate the transportation of molecules to NPC (Schwoebel and Moore, 2000; Weis, 2003). By constituting NPC assembly, nucleoporins have differing roles such as establishing nuclear membrane protein localization, facilitating nuclear import and export process and providing the interaction sites for the nucleoplasmic transport (Walde and Kehlenbach, 2010; Hoelz et al., 2011; Solmaz et al., 2011; Busayavalasa et al., 2012).
Besides the trafficking function, NPCs are known to be involved in many cellular processes that include transcriptional regulation, chromatin organization and cell differentiation (Gomez-Cavazos and Hetzer, 2012). Several studies reported that nucleoporins are expressed cell-specifically and the composition of NPC may vary among the expressing cells.

Nup210 (or gp210), a component of NPC assembly, is a membrane-spanning glycoprotein with single transmembrane domain and anchors NPC to the nuclear membrane (Hoelz et al., 2011). Nup210 is also found to be highly conservative across eukaryotes including its yeast homologue Pom152 (Upla et al., 2017) suggesting the evolutionary importance of this glycoprotein. Additionally, it was reported that Nup210 along with other nucleoporins Nup133 and Nup98 were involved in transportation of transcription factors involved in

+ To whom correspondence should be addressed : oh5ow@naver.com 
neural lineage specific differentiation in embryonic stem cells (Lupu et al., 2008; D'Angelo et al., 2012; Liang et al., 2013). Nup210 expression was increased during neuron cell differentiation while the knock-down of Nup210 disrupted the neural differentiation and the expression of differentiationassociated genes. Recently, it was also reported that Nup210 was involved in muscle differentiation and calcium homeostasis. This was based on the fact that Nup210-deficiency caused stress response in the endoplasmic reticulum during muscle differentiation leading to cell apoptosis (GomezCavazos and Hetzer, 2015). Moreover, Nup210 promoted the assembly of Mef2C transcription complex that was essential for the expression of NPC muscle structural genes which regulated muscle growth and maintenance in zebrafish (Raices et al., 2017).

There are several reports that Nup210 may be involved in autoimmune disease in human including primary biliary cirrhosis (PBC), rheumatic disease and systemic lupus erythematosus (Worman and Courvalin, 2003; Enarson et al., 2004; Duarte-Rey et al., 2012). Primary biliary cirrhosis (PBC) is an autoimmune disease that destructs bile ducts and causes liver cirrhosis. Autoantibody of Nup210 were found in the severe PBC patients and the abnormal expression of Nup210 which is the autoimmune target of PBC might cause this disease (Nakamura et al., 2006). In this study, we analyzed the amino acid sequence and the gene expression profile of chicken Nup210 in various chicken tissues and chicken DF-1 cells.

\section{MATERIALS AND METHODS}

\section{Cell Culture}

The chicken cell lines DF-1 were purchased from the American Tissue Culture Collection (ATCC, Manassas, VA, USA). DF-1 cells were cultured in DMEM (Biowest, USA) medium with $10 \%$ fetal bovine serum (FBS), $2 \mathrm{mM}$ L-glutamine and $100 \mathrm{U} / \mathrm{mL}$ of penicillin and streptomycin (Thermo Scientific, Logan, UT, USA), respectively, at $37^{\circ} \mathrm{C}$ with $5 \% \mathrm{CO}_{2}$ in humidified atmosphere.

\section{Treatment of Poly $(\mid: C)$ and Transcription Factor Inhibitors}

Poly (I:C) was purchased from Invivogen (San Diego, CA,
USA) and treated in chicken DF-1 cells at the concentrations of $0.1,1,5$, and $10 \mu \mathrm{g} / \mathrm{mL}$ for $24 \mathrm{~h}$. The time-dependent effect of Poly (I:C) was analyzed by treatment for 1, 3, 6, 12 , and $24 \mathrm{~h}$ at $10 \mu \mathrm{g} / \mathrm{mL}$ prior to gene expression analysis. Transcription factor inhibitors (BAY 11-7085 for NFkB and Tanshinone IIA for AP-1) were purchased from Sigma-Aldrich (Louis, MO, USA). The inhibitors were added on DF-1 cells with concentrations of $5 \mu \mathrm{M}$ for BAY 11-7085 and $25 \mu \mathrm{M}$ for Tanshinone IIA at $3 \mathrm{~h}$ prior to the treatment with $5 \mu \mathrm{g} / \mathrm{mL}$ poly (I:C).

\section{Bioinformatic Analysis}

The mRNA and amino acid sequences of various species (chicken, duck, human, chimpanzee, mouse, rat, cow, pig, horse, dog, and cat) for Nup210 were retrieved from the Ensemble database (http://www.ensembl.org/) (Table 1). The amino acid sequences were aligned by ClustalW method in BioEdit software. The protein domains were predicted by using the SMART domain search program (http://smart.emblheidelberg.de/). Phylogenetic analyses were performed with MEGA7 software (Kumar et al., 2016).

\section{RNA Extraction and cDNA Synthesis}

Total RNA was isolated from chicken DF-1 cells according to Trizol reagent (Life Technologies, USA) manufacturer's instructions. Total RNA were quantified at $260 \mathrm{~nm}$ absorbance and RNA integrity was evaluated with $1.0 \%(\mathrm{w} / \mathrm{v})$ agarose gel. cDNA was reverse-transcribed from $2 \mu \mathrm{g}$ of total RNA (amounts) using QuantiTect Reverse Transcription Kit (Toyobo, JAPAN) according to the manufacturer's instructions.

\section{Quantitative Real-time Polymerase Chain Reaction (qRT-PCR) Analysis}

The expression level of chNup210 gene was confirmed in DF-1 cells by qPCR method (Oh et al., 2019). Briefly, SYBR green supermix and $\mathrm{CFX} 96^{\mathrm{TM}}$ IVD Real-time PCR System (Bio-rad, USA) were used for $\mathrm{qPCR}$, and relative quantification $\mathrm{Ct}\left(2^{-\Delta \Delta \mathrm{CT}}\right)$ method was applied to compare the gene expression levels (Livak and Schmittgen, 2001). The PCR were performed as follows: an initial step at $94^{\circ} \mathrm{C}$ for $3 \mathrm{~min}$; 39 cycles at $94^{\circ} \mathrm{C}$ for $10 \mathrm{~s}, 60^{\circ} \mathrm{C}$ for $30 \mathrm{~s}$, and $72^{\circ} \mathrm{C}$ for 30 $\mathrm{s}$; and a final step at $72^{\circ} \mathrm{C}$ for $10 \mathrm{~min}$. Dissociation was 
Table 1. Ensembl and amino acid sequence ID in the Nup210 gene of various species

\begin{tabular}{cccc}
\hline \hline Species & Scientific name & Ensembl ID & NCBI Reference Sequence ID \\
\hline Chicken & Gallus gallus & ENSGALG00000005078 & XM_414320.6 \\
Duck & Anas platyrhynchos & ENSAPLG00000012355 & XM_013091930.2 \\
Human & Homo sapiens & ENSG00000132182 & NM_024923.3 \\
Chimpanzee & Pan troglodytes & ENSPTRT00000027394 & XM_003309631.4 \\
Mouse & Mus musculus & ENSMUSG00000030091 & NM_018815.2 \\
Rat & Rattus norvegicus & ENSRNOG00000005390 & NM_053322.2 \\
Cow & Bos taurus & ENSBTAT000000043850 & NM_001191461.1 \\
Pig & Sus scrofa & ENSSSCT00000054838 & XM_021069388.1 \\
Horse & Equus caballus & ENSECAG00000009171 & XM_014731350.1 \\
Dog & Canis & ENSCAFT00000007053 & XM_005632290.3 \\
Cat & Felis catus & ENSFCAT00000007507 & XM_019825131.1 \\
Zebrafish & Danio rerio & ENSDARG00000063333 & XM_002667560.6 \\
\hline
\end{tabular}

performed at $0.5^{\circ} \mathrm{C}$ increments from $55^{\circ} \mathrm{C}$ to $95^{\circ} \mathrm{C}$ for over 25 min. For the endogenous control, glyceraldehyde-3-phosphate dehydrogenase (GAPDH) was used to detect mRNA expression levels. The GAPDH primer sequences are as follows: 5'- TGC TGC CCA GAA CAT CAT CC -3' for forward primer and 5'-ACG GCA GGT CAG GTC AAC AA -3' for reverse primer.

\section{Statistical Analysis}

Statistical significance was assessed using Student's $t$-test and $P<0.05$ was considered significant compared to vehicle control. The difference among each value was determined by Tukey's multiple comparison test with alpha $<0.05$ were considered significant.

\section{RESULTS AND DISCUSSION}

The amino acid sequence of chNup210 in chicken was analyzed and compared with other species. The chNup210 gene sequence was identified as a DEG from chicken kidney RNA-seq study (Park et al., 2017). The resultant amino acid sequence of chNup210 gene and the sequences of Nup210 from other animals including duck, horse, dog, cat, mouse, rat, pig, cow, human and chimpanzee that were retrieved from Ensemble database are shown in Fig. 1A. From the alignment with GeneDoc 2.7 program, it was found out that Nup210 was highly conserved among the species. Based on the prediction with SMART domain search program, chNup210 was found to comprise of bacterial Ig-like domain 2 (Big-2) and transmembrane domain as like other species. The evolutionary relationships between chNup210 and other Nup210 orthologs are shown by phylogenetic tree (Fig. 1B). Based on the amino acid sequence alignment, it was revealed that chNup210 was evolutionary clustered in the same clade as that of the duck than for other mammals.

The gene expression pattern of chicken Nup210 was investigated in various chicken tissues. From this study, it was revealed that chNup 210 gene was highly expressed in chicken lung and spleen tissues (Fig. 2A). This result contradicts other studies where Nup210 gene expression is known to be related to muscle and neural cell differentiation and autoimmune diseases of bile and liver (Enarson et al., 2004; Duarte-Rey et al., 2012). Therefore, the high expression chNup210 in chicken lung and spleen under normal condition is somewhat intriguing.

The transcriptional profile of chicken Nup210 was also investigated in chicken DF-1 cells under the stimulation with TLR-3/Mda-5 agonist, poly (I:C). As shown in Fig. 2B, the expressional level of chNup210 after stimulation with $10 \mu \mathrm{g} / \mathrm{mL}$ 
(A)

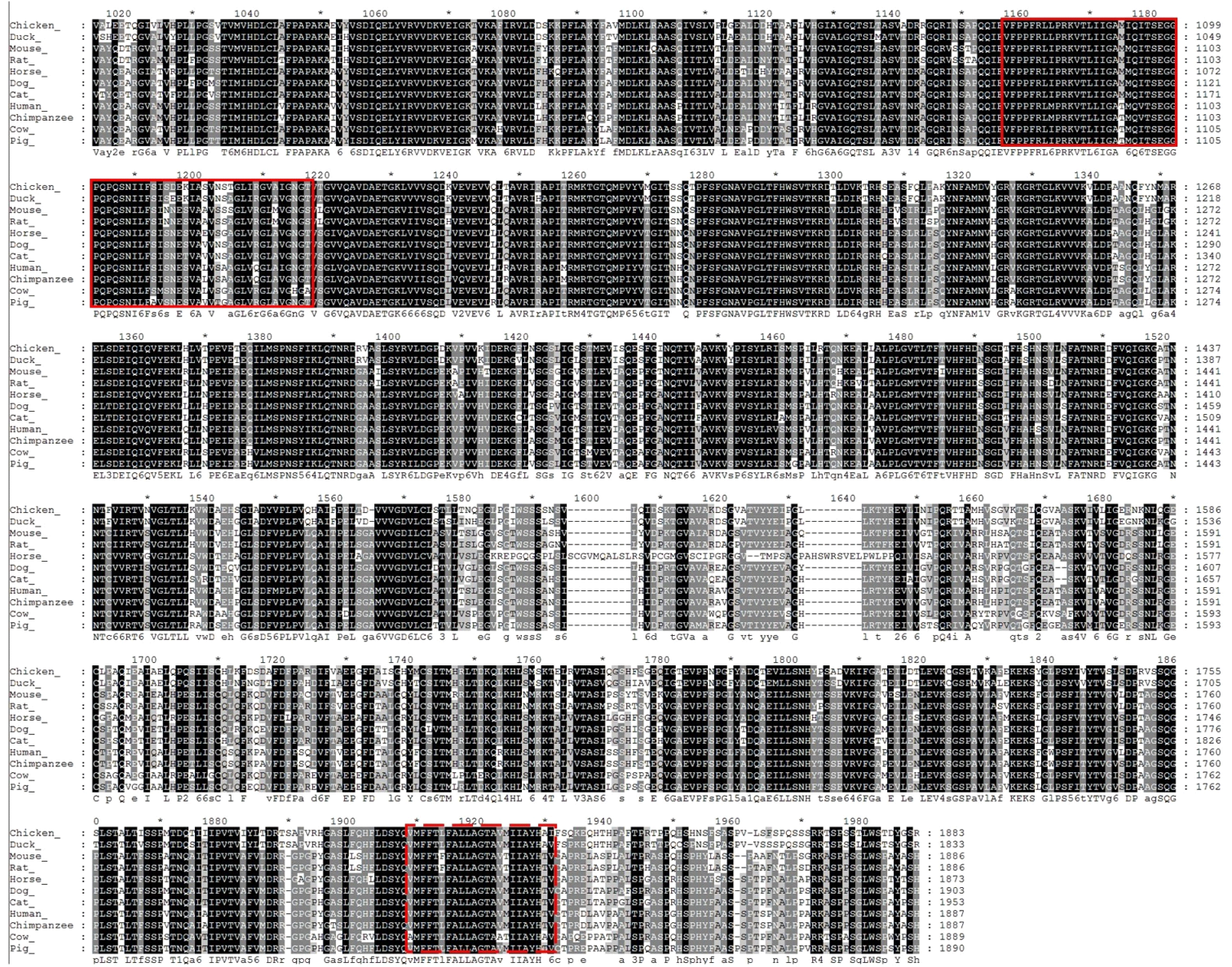

(B)

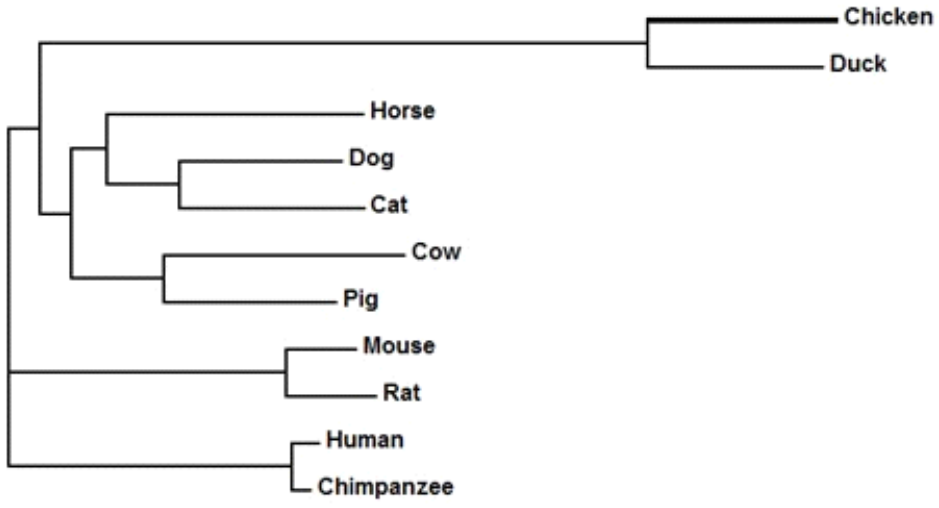

$\stackrel{0.02}{1}$

Fig. 1. Analysis of Nup210 amino acid sequences.

(A) Comparison of the chicken Nup210 amino acid sequence with those of various other species. ChNup210 was predicted to comprise bacterial Ig-like domain 2 (Big-2) (solid box), Transmembrane domain (dotted box). (B) Phylogenetic tree for Nup210 from various species. Phylogenetic analyses were performed with the amino acid sequence of each species, using MEGA7 software. ChNup210 clustered in the same clade with duck. The bar indicates $2 \%$ amino acid divergence. 
(A)

NUP210

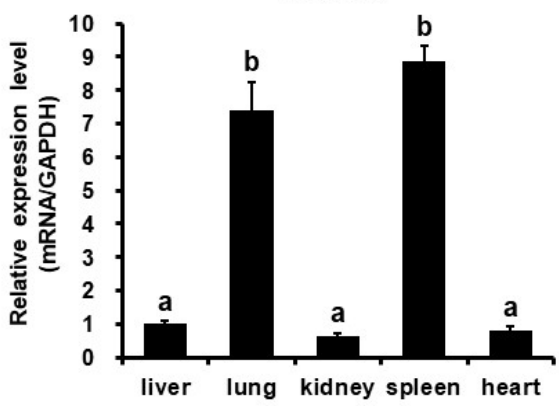

(B)

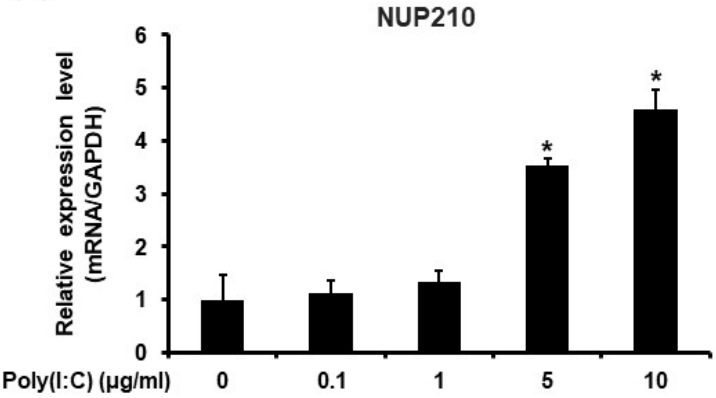

(C)

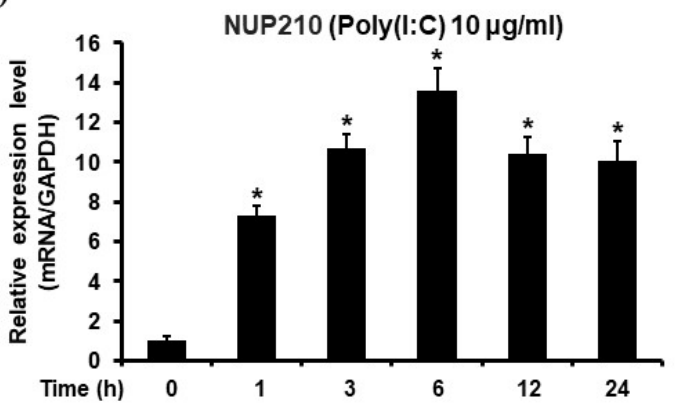

Fig. 2. (A) Analysis of expression levels of chNup210 in different chicken tissues (liver, lung, kidney, spleen, and heart). (B) chNup210 in chicken DF-1 cells after poly (I:C) treatment. DF-1 cells were treated with $0.1,1,5,10 \mu \mathrm{g} / \mathrm{mL}$ of poly (I:C) for 24 h. (C) DF-1 cells were treated with $10 \mu \mathrm{g} / \mathrm{mL}$ poly (I:C) for $1,3,6,12$ and $24 \mathrm{~h}$. The experiment was repeated for three times $(\mathrm{n}=3)$. Significant differences were determined by Tukey's multiple comparison test, and ${ }^{*}$ means $P<0.05$.

of poly (I:C) was highly elevated. This result suggests that the expression of chNup210 could be induced by viral infection in chicken cell and thus chNup210 may be related to TLR3-mediated immune responses. To further study the hypothesis that the up-regulation of chNup210 was due to TLR signaling, transcriptional inhibitors of TLR3 signal pathway were added in chicken DF-1 cell. The inhibitors of transcription factors NF-kB and AP-1 used were BAY 11-7085 (Bay) and Tanshinone IIA (Tan-II), respectively. The expressional level of $\operatorname{chILIB}$ evaluated after poly (I:C) treatment in the presence of inhibitors Bay or Tan-II is shown in Fig. 3. In this study, the transcriptional levels of chNup210, along with $\operatorname{chIL1B}$, were all up-regulated after treatment of $5 \mu \mathrm{g} / \mathrm{mL}$ of poly (I:C) without the inhibitors. However, under the presence of transcriptional inhibitors, the up-regulations of chNup210 and chIL1B genes were significantly suppressed compared to poly (I:C)-only treatment. This suggests that the expressions of chNup210 and chIL1B genes were all induced by transcriptional factors NF- $\mathrm{KB}$ and $\mathrm{AP}-1$ under the stimu- lation of poly (I:C) and chNup210 expression seemed to be under control of TLR3 signaling pathway in chicken.

Although several studied have shown that the functions of Nup210 are related to cell differentiations and autoimmune diseases, this study revealed the expression of chNup 210 in TLR3 signaling pathway in the fowl. As a result, chNup210 may play a significant role during viral inflammation in chicken. This study therefore provides the fundamental information about the expression Nup210 in chicken and further studies that can generate more insight on the involvement of chNup210 in the chicken innate immune response against viral infection are recommended.

\section{적 요}

Nucleoporin 210(Nup210)는 근육 및 신경세포의 분화, 자 기 면역 질환, 말초 $\mathrm{T}$ 세포 항상성 등 여러 생리작용에 관여 한다. 닭의 Nup210 유전자는 닭 신장조직에서 칼슘 의존성 차별 발현 유전자로 발굴되었으며, 닭의 대사 이상 질환과 
(A)

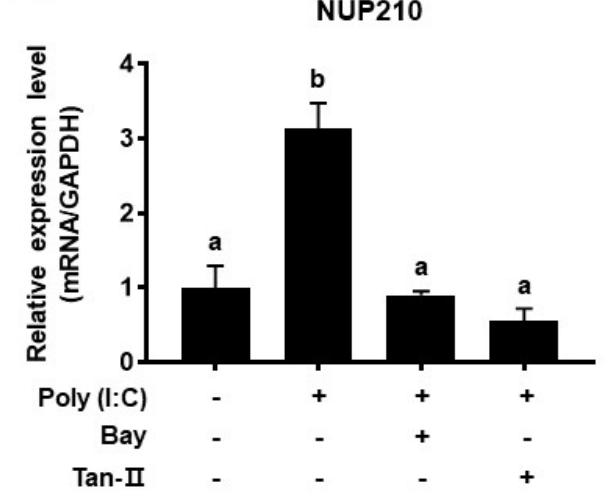

IL1B

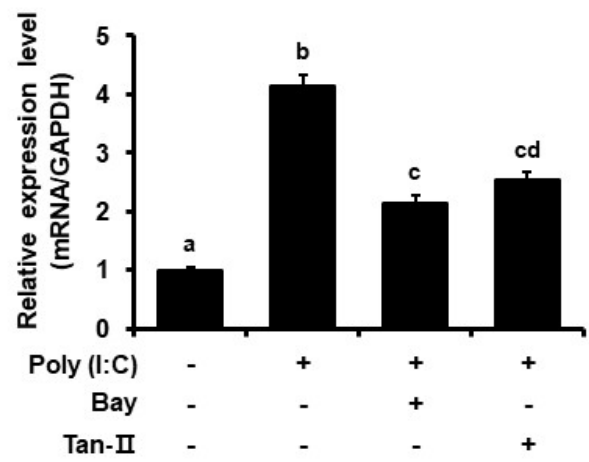

Fig. 3. Effects of NFkB inhibitor (BAY11-7085; Bay) and AP-1 inhibitor (Tanshinone IIA; Tan-II) on the gene expression of chNup210 and chILIB after stimulation with poly (I:C) in the cultured DF-1 fibroblast cells.

Cultured DF-1 cells were treated with or without poly (I:C) $(5 \mu \mathrm{g} / \mathrm{mL}, 6 \mathrm{~h})$ in the presence or absence of Bay $(5 \mu \mathrm{M})$ and Tan-II $(25$ $\mu M)$. Values are mean $\pm S E(n=3)$. Significant differences were determined by Tukey's multiple comparison test, and bars with the same letter $(\mathrm{a} \sim \mathrm{d})$ on top are the cases that significant differences were not found $(P>0.05)$.

Nup210의 관련 연구를 위해 Nup210 유전자의 분자유전학 적 특성을 구명하고, 톨-유사수용체 3(Toll-like receptor 3 (TLR3)) 자극에 의한 전사 조절을 연구하였다. 닭의 여러 조 직과 배아 섬유아세포주인 DF-1 세포에서 Nup210 유전자의 전사 수준을 조사한 결과, 폐와 비장 조직에서 가장 높게 발 현되었으며, Nup 210 의 발현은 TLR3 신호자극에 의해 증가 함을 확인하였다. 또한 닭 Nup210 유전자가 코딩하는 단백 질의 구조는 조류, 어류, 포유류를 포함한 여러 종과 매우 보존적이나 진화적으로 다른 포유류보다는 오리와 가장 가 깝다고 추정되었다. 본 연구의 결과를 통해 닭 Nup210이 TLR3 신호시스템에 관여함을 확인하였고, 추가연구를 통해 바이러스 침입에 대한 닭 면역 메커니즘을 구명할 필요가 있다고 사료된다.

(색인어: 닭, Nup210, Toll-like receptor 3, 유전자 발현, 선 천적 면역수용체 신호전달)

\section{ACKNOWLEDGMENTS}

This work was supported by a grant from the NextGeneration BioGreen 21 Program (No. PJ01324201, PJ01315 101), Rural Development Administration, Republic of Korea.

\section{ORCID}

Marc Ndimukaga https://orcid.org/0000-0001-8061-7753

\begin{abstract}
Godfrey Bigirwa
https://orcid.org/0000-0002-5584-4273

Seokhyun Lee

https://orcid.org/0000-0001-9985-5380

Raham Lee

https://orcid.org/0000-0002-4928-9517

Jae-Don Oh

https://orcid.org/0000-0001-7756-1330
\end{abstract}

\section{REFERENCES}

Busayavalasa K, Chen X, Farrants AK, Wagner N, Sabri N 2012 The Nup155-mediated organisation of inner nuclear membrane proteins is independent of Nup155 anchoring to the metazoan nuclear pore complex. J Cell Sci $125(\mathrm{Pt}$ 18):4214-4218.

D'Angelo MA, Gomez-Cavazos JS, Mei A, Lackner DH, Hetzer MW 2012 A change in nuclear pore complex composition regulates cell differentiation. Dev Cell 22(2): 446-458.

Duarte-Rey C, Bogdanos D, Yang CY, Roberts K, Leung PS, Anaya JM, Worman HJ, Gershwin ME 2012 Primary biliary cirrhosis and the nuclear pore complex. Autoimmun Rev 11(12):898-902.

Enarson P, Rattner JB, Ou Y, Miyachi K, Horigome T, Fritzler MJ 2004 Autoantigens of the nuclear pore complex. J Mol Med (Berl) 82(7):423-433.

Gomez-Cavazos JS, Hetzer MW 2012 Outfits for different occasions: tissue-specific roles of nuclear envelope proteins. 
Curr Opin Cell Biol 24(6):775-783.

Gomez-Cavazos JS, Hetzer MW 2015 The nucleoporin gp210/Nup210 controls muscle differentiation by regulating nuclear envelope/ER homeostasis. J Cell Biol 208(6): 671-681.

Hoelz A, Debler EW, Blobel G 2011 The structure of the nuclear pore complex. Annu Rev Biochem 80:613-643.

Kumar S, Stecher G, Tamura K 2016 MEGA7: molecular evolutionary genetics analysis version 7.0 for bigger datasets. Mol Biol Evol 33(7):1870-1874.

Liang Y, Franks TM, Marchetto MC, Gage FH, Hetzer MW 2013 Dynamic association of NUP98 with the human genome. PLoS Genet 9(2):e1003308.

Livak KJ, Schmittgen TD 2001 Analysis of relative gene expression data using real-time quantitative PCR and the 2(-Delta Delta C(T)) method. Methods 25(4):402-408.

Lupu F, Alves A, Anderson K, Doye V, Lacy E 2008 Nuclear pore composition regulates neural stem/progenitor cell differentiation in the mouse embryo. Dev Cell 14(6):831-842.

Nakamura M, Takii Y, Ito M, Komori A, Yokoyama T, Shimizu-Yoshida Y, Koyabu M, Matsuyama M, Mori T, Kamihira T, Daikoku M, Migita K, Yatsuhashi H, Nozaki N, Shimoda S, Ishibashi H 2006 Increased expression of nuclear envelope gp210 antigen in small bile ducts in primary biliary cirrhosis. J Autoimmun 26(2):138-145.

Oh J-D, Bigirwa G, Lee S, Song K-D 2019 Molecular characterization and expression analysis of clathrinassociated adaptor protein 3- $\delta$ subunit 2 (AP3S2) in chicken. Korean J Poult Sci 46(1):31-37.

Park W, Rengaraj D, Kil DY, Kim H, Lee HK, Song KD
2017 RNA-seq analysis of the kidneys of broiler chickens fed diets containing different concentrations of calcium. Sci Rep 7(1):11740.

Raices M, Bukata L, Sakuma S, Borlido J, Hernandez LS, Hart DO, D'Angelo MA 2017 Nuclear pores regulate muscle development and maintenance by assembling a localized Mef2C complex. Dev Cell 41(5):540-554 e547.

Schwoebel ED, Moore MS 2000 The control of gene expression by regulated nuclear transport. Essays Biochem 36:105-113.

Solmaz SR, Chauhan R, Blobel G, Melcak I 2011 Molecular architecture of the transport channel of the nuclear pore complex. Cell 147(3):590-602.

Upla P, Kim SJ, Sampathkumar P, Dutta K, Cahill SM, Chemmama IE, Williams R, Bonanno JB, Rice WJ, Stokes DL, Cowburn D, Almo SC, Sali A, Rout MP, Fernandez-Martinez J 2017 Molecular architecture of the major membrane ring component of the nuclear pore complex. Structure 25(3):434-445.

Walde S, Kehlenbach RH 2010 The part and the whole: functions of nucleoporins in nucleocytoplasmic transport. Trends Cell Biol 20(8):461-469.

Weis K 2003 Regulating access to the genome: nucleocytoplasmic transport throughout the cell cycle. Cell 112(4): 441-451.

Worman HJ, Courvalin JC 2003 Antinuclear antibodies specific for primary biliary cirrhosis. Autoimmun Rev 2(4):211217.

Received Aug. 27, 2019, Revised Sep. 27, 2019, Accepted Sep. 27, 2019 
